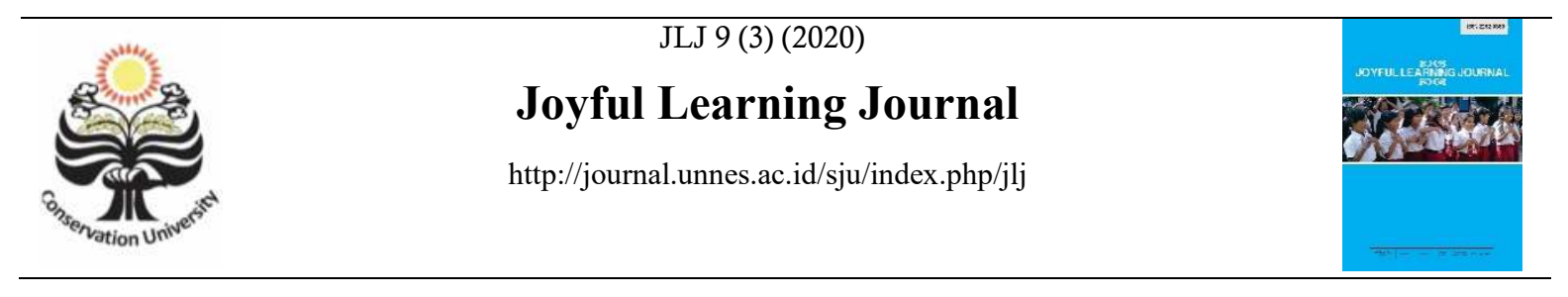

\title{
KEEFEKTIFAN MODEL CONTEXTUAL TEACHING AND LEARNING (CTL) BERBASIS LINGKUNGAN
}

\author{
Dewi Wahyu Kartika ${ }^{\bowtie}$, Desi Wulandari
}

Jurusan Pendidikan Guru Sekolah Dasar, Fakultas Ilmu Pendidikan, Universitas Negeri Semarang, Indonesia

\begin{abstract}
Info Artikel Abstrak
Sejarah Artikel:

Pelaksanaan pembelajaran IPA kelas IV SDN Gugus Jendral Sudirman cenderung ceramah, belum dikaitkan Diterima Juli 2020 dengan kehidupan sehari-hari serta belum memberikan kesempatan siswa untuk menemukan konsep materi Disetujui Agustus 2020 sendiri. Penelitian ini bertujuan untuk menguji keefektifan model CTL berbasis lingkungan terhadap hasil Dipublikasikan belajar IPA. Penelitian ini adalah penelitian eksperimen menggunakan quasi experimental design bentuk September 2020

\section{Keywords:} nonequivalent control group design. Variabel bebas dalam penelitian ini adalah model CTL berbasis lingkungan sedangkan variabel terikatnya yaitu hasil belajar IPA. Teknik pengambilan sampel menggunakan CTL Model; effectiveness ;Teknik analisis data yang digunakan adalah analisis awal (uji normalitas dan homogenitas); analisis deskriptif; learning outcomes; $\quad$ analisis akhir (independent sample t-test dan n-gain). Hasil independentsamples t-test menunjukkan science $t_{\text {hitung }}>t_{\text {tabel }}(6,818>1,666)$, dan uji n-gain menunjukkan peningkatan kelas eksperimen berada pada kriteria sedang yaitu 0,534, sedangkan kelas kontrol berada pada kriteria rendah yaitu 0,295. Simpulan dari penelitian ini adalah model CTL berbasis lingkungan lebih efektif diterapkan dalam pembelajaran IPA pada siswa kelas IV SDN Gugus Jendral Sudirman Kecamatan Kayen Kabupaten Pati dibandingkan dengan model DI
\end{abstract}

\begin{abstract}
The implementation of the fourth grade science lesson at SDN Gugus Jendral Sudirman tends to lecture, has not been linked to daily life and has not given students the opportunity to find the concept of their own material. This study aims to examine the effectiveness of the environmental-based CTL model on science learning outcomes. This research is an experimental study used a quasi experimental design form nonequivalent contro group design. The independent variable in this study is the environmental-based CTL model, while the dependent variable is the science learning outcomes. The sampling technique used purposive sampling. Data collection techniques used interviews, observation, documentation, and tests. The data analysis technique usea was the initial analysis (normality and homogeneity test); descriptive analysis; final analysis (independent sample $t$-test and $n$-gain). The results of the independent samples $t$-test showed tcount $>$ ttable $(6.818>1.666)$, and the n-gain test showed that the increase in the experimental class was at the moderate criteria, namely 0.534 , while the control class was in the low criterion, namely 0.295. The conclusion from this study is that the environmentally based CTL model is more effective in teaching science for fourth grade students of SDN Gugus Jendral Sudirman, Kayen District, Pati Regency compared to the DI model.
\end{abstract}

(C) 2020 Universitas Negeri Semarang

Alamat korespondensi

ISSN 2252-6366

Jatiroto RT 04 RW IV, Kayen, Pati, 59171

E-mail: dewiwk21@gmail.com 


\section{PENDAHULUAN}

Pendidikan merupakan upaya yang direncanakan dengan menerbitkan semangat belajar guna menciptakan proses pembelajaran yang efektif sehingga membentuk pribadi yang berwatak luhur, unggul, dan terpelajar. Hal tersebut sesuai dengan tujuan nasional Bangsa Indonesia yang terdapat dalam Pembukaan UUD 1945 alinea keempat yaitu mencerdaskan kehidupan bangsa. Untuk mencapai tujuannya, pendidikan direncanakan dan disusun sesuai dengan kurikulum yang berlaku. Tujuan kurikulum yang tercantum dalam Peraturan Menteri Pendidikan dan Kebudayaan Nomor 37 Tahun 2018 meliputi 4 kecakapan, antara lain kecakapan sikap spiritual, sikap sosial, pengetahuan, dan keterampilan. Ketercapaian tujuan kurikulum tersebut dilakukan dengan proses yang konsekuen sesuai standar proses yang diatur dalam Peraturan Menteri Pendidikan dan Kebudayaan Nomor 22 Tahun 2016. Pada pembelajaran di sekolah dasar, terdapat beberapa muatan pelajaran yang harus dipahami oleh peserta didik. Berdasarkan lampiran Peraturan Menteri Pendidikan dan Kebudayaan Nomor 21 Tahun 2016, IPA adalah salah satu muatan pelajaran yang harus dikuasai oleh peserta didik pada tingkat SD/MI.

Cita-cita maupun tujuan pembelajaran tersebut sudah ideal. Namun kenyataannya hal tersebut belum terealisasi secara optimal. Dibuktikan dengan Hasil Programme for International Students Assessment (PISA) pada tahun 2018 yang menyatakan Indonesia terletak pada urutan 70 dari 78 negara, dan hasil Trends Internasional in Mathematics and Science Study (TIMSS) tahun 2015 yang menunjukan Indonesia menduduki urutan 45 dari 48 negara. Selain itu, penurunan hasil Ujian Nasional juga dialami oleh peserta didik tingkat SD. Penurunan nilai USBN tersebut selaras dengan hasil belajar IPA Siswa Kelas IV SD Gugus Jendral Sudirman yang masih rendah.

Pra-penelitian yang dilakukan peneliti, menunjukkan bahwa permasalahan yang mempengaruhi hasil belajar IPA tersebut yaitu guru belum memanfaatkan model pembelajaran yang berpusat pada siswa, sehingga siswa belum dilibatkan secara aktif dalam proses pembelajaran. Metode yang dimanfaatkan oleh guru cenderung ceramah serta belum memberikan kesempatan kepada siswa untuk menemukan konsep materi sendiri. Guru sudah menumbuhkan sikap kerja sama antar siswa dengan diskusi kelompok. Namun pembentukan kelompok hanya berdasarkan tempat duduk siswa dan belum dilakukan secara heterogen berdasarkan kemampuan siswa. Siswa cenderung tidak memperhatikan guru saat menjelaskan materi dan asyik bermain sendiri. Kurangnya alat peraga yang diberikan guru membuat siswa kurang tertarik dalam pembelajaran.

Permasalahan pembelajaran tersebut didukung dari data nilai PTS di SDN Gugus Jendral Sudirman yang belum mencapai ketuntasan belajar, yaitu dari jumlah 106 siswa terdapat 42 siswa $(39,6 \%)$ nilainya masih dibawah Kriteria Ketuntasan Minimal (KKM) dan 64 siswa $(60,4 \%)$ sudah diatas KKM, sedangkan menurut Djamarah (2010: 108) pembelajaran dapat dinyatakan berhasil jika $75 \%$ atau lebih dari jumlah siswa yang mengikuti proses pembelajaran dapat mencapai mencapai KKM yang telah diterapkan oleh satuan pendidikan. Oleh karena itu SDN Gugus Jendral Sudirman belum mencapai keberhasilan hasil belajar sehingga diperlukan suatu perubahan pada proses pembelajaran untuk mengatasi permasalahan pada hasil belajar.

Guru dapat memanfaatkan model pembelajaran Contextual Teaching and Learning (CTL). Shoimin (2010:41) dalam buku "68 Model Pembelajaran Inovatif" mengemukakan bahwa model pembelajaran CTL adalah konsep belajar dengan cara membawakan kondisi dunia nyata ke dalam kelas serta memotivasi peserta didik untuk membuat kaitan antara pengetahuan yang diketahuinya dengan penerapan aktivitas seharihari sehingga mewujudkan pembelajaran yang kian bermakna bagi peserta didik. Noor (2015:74) menambahkan bahwa pendekatan kontekstual merupakan pendekatan pembelajaran yang dapat memacu motivasi belajar siswa.

Penelitian yang mendukung penelitian ini yaitu penelitian yang dilakukan oleh Chairina Nasir, dkk (2016) dengan judul Figuring The Context of Contextual Teaching and Learning (CTL) Under The 2013 Curriculum. Berdasarkan penelitian tersebut, penerapan model kontekstual dalam pembelajaran dapat menciptakan suasana belajar yang mengasyikkan, membuat peserta didik terlibat aktif, dan mampu menghubungkan materi dengan kehidupan sehari-hari. Penelitian yang dilaksanakan oleh Muhammad Mifta Fausan dan Indah Panca Pujiastuti pada tahun 2017 dengan judul Pengaruh Pendekatan CTL Berbasis NHT terhadap Motivasi, Hasil Belajar IPA, dan Retensi Siswa juga relevan dengan penelitian ini. Hasil uji Independent Sample T-Test menyatakan signifikansi kurang dari 0,05 sehingga pendekatan CTL berbasis NHT efektif terhadap variabel terikat penelitian.

Rumusan masalah dalam penelitian ini adalah "Apakah model Contextual Teaching and Learning (CTL) berbasis lingkungan lebih efektif terhadap hasil belajar IPA siswa kelas IV SDN Gugus Jendral Sudirman Kecamatan Kayen 
Kabupaten Pati bila dibandingkan dengan model Direct Instruction (DI)?"

Penelitian ini bertujuan untuk menguji keefektifan model pembelajaran Contextual Teaching and Learning (CTL) berbasis lingkungan terhadap hasil belajar IPA siswa kelas IV SDN Gugus Jendral Sudirman Kecamatan Kayen Kabupaten Pati.

\section{METODE PENELITIAN}

Pendekatan penelitian ini adalah metode kuantitatif dengan jenis penelitian eksperimen. Desain penelitian ini adalah quasi experimental design berbentuk nonequivalent control group design. Populasi penelitian ini adalah seluruh siswa kelas IV SDN Gugus Jendral Sudirman Kecamatan Kayen Kabupaten Pati tahun pelajaran 2019/2020. Teknik pengambilan sampel yang digunakan adalah purposive sampling sehingga sampel penelitian ini adalah SDN Jatiroto 01 dan SDN Brati 01 sebagai kelas eksperimen serta SDN Jatiroto 02 dan SDN Jatiroto 03 sebagai kelas kontrol.

Instrumen yang digunakan adalah soal pretest dan posttest. Penelitian ini terdiri atas dua variabel yaitu model CTL berbasis lingkungan sebagai variabel bebas $(X)$ dan hasil belajar IPA siswa kelas IV sebagai variabel terikat (Y). Hasil belajar yang digunakan pada penelitian ini adalah hasil belajar kognitif siswa. Penelitian ini dilakukan sebanyak 4 kali pertemuan pada masing-masing kelas penelitian. Teknik pengumpulan data dalam penelitian ini meliputi teknik tes dan non tes (wawancara, observasi, dan dokumentasi). Teknik analisis data yang digunakan adalah: (1) analisis data awal meliputi uji normalitas dan uji homogenitas; (2) analisis deskriptif; (3) analisis data akhir meliputi uji hipotesis dan uji n-gain.

\section{HASIL PENELITIAN DAN PEMBAHASAN}

\section{Analisis Data Awal}

Analisis data tahap awal bertujuan untuk mengetahui kondisi awal kelas eksperimen dan kontrol pada kondisi yang homogen atau tidak.

\section{Uji Normalitas Nilai Pretest}

Uji normalitas dalam penelitian ini, dianalisis dengan Kolmogorov Smirnov dengan bantuan SPSS 24. Hasil uji normalitas pada kelas eksperimen dan kelas kontrol berturut-turut sebesar 0,081 dan 0,062 yang artinya asumsi normalitas dapat terpenuhi karena nilai sig $>0,05$.

$\begin{array}{ccr}\text { Uji Homogenitas Nilai Pretest } & \\ \text { Uji } & \text { homogenitas dianalisis } \\ \text { menggunakan } & \text { One-Way ANOVA dengan }\end{array}$

bantuan SPSS 24. Hasil Uji homogenitas menunjukkan nilai signifikansi sebesar 0,843 . Hal ini berarti data telah memenuhi asumsi homogenitas atau memiliki varian yang sama karena nilai sig $>0,05$.

\section{Analisis Deskriptif Data Pendukung Penelitian \\ Hasil Pengamatan Model CTL Berbasis Lingkungan}

Hasil analisis observasi penerapan model CTL berbasis lingkungan pada muatan pelajaran IPA disajikan pada diagram 1 berikut.

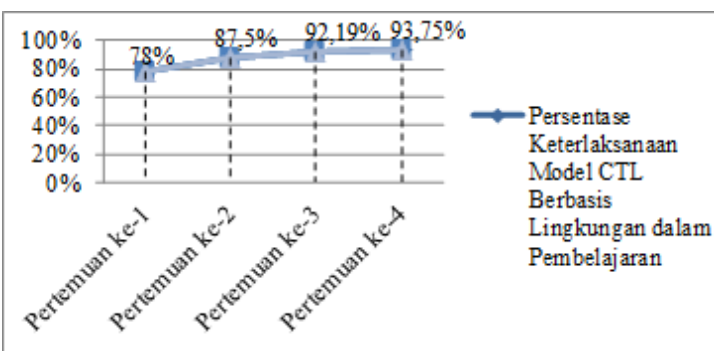

Diagram 1. Hasil Pengamatan Penerapan Model CTL Berbasis Lingkungan

Berdasarkan diagram 1 menunjukkan terjadi peningkatan keterlaksanaan model $C T L$ berbasis lingkungan dari pertemuan pertama sampai pertemuan keempat pada kelas eksperimen.

\section{Hasil Observasi pada Ranah Psikomotorik dan Kognitif}

Hasil observasi pada ranah psikomotorik kelas eksperimen dan kontrol disajikan pada tabel 1 berikut

Tabel 1. Hasil Observasi pada Ranah Psikomotorik

Rata-rata Penilaian Psikomotorik

\begin{tabular}{lcccc} 
Kelas & \multicolumn{4}{c}{ Pertemuan ke- } \\
\cline { 2 - 5 } & 1 & 2 & 3 & 4 \\
\hline Eksperimen & 83,33 & 93,57 & 90,95 & 91,54 \\
Kontrol & 75,00 & 73,36 & 80,93 & 84,62
\end{tabular}

Berdasarkan tabel 1, peserta didik di kelas eksperimen memperoleh rata-rata nilai psikomotorik yang lebih tinggi. Pada kelas eksperimen, kelompok dibentuk secara heterogen berdasarkan kemampuan peserta didik. Hal ini membuat peserta didik dapat berdiskusi bersama anggota kelompoknya dengan baik sehingga dapat memecahkan permasalahan yang diberikan dalam LKPD. Peserta didik yang biasanya malas dalam 
sekitarnya, serta mendapat tantangan baru karena berhadapan langsung dengan obyek yang sebenarnya.

Pada pertemuan pertama, pembelajaran bertujuan untuk memahami macam-macam gaya serta pengertian gaya otot dan pengaruhnya terhadap benda menggunakan media sepeda, kertas dan bola. Sepeda dipilih oleh peneliti karena mayoritas siswa menaiki sepeda ketika berangkat ke sekolah. Media lain seperti kertas dan bola juga mudah dijumpai karena terdapat di sekolah. Indikator yang dikembangkan pada pertemuan kedua adalah menganalisis pemanfaatan gaya otot. Media yang digunakan juga merupakan media konkret seperti buku dan bola. Pada pertemuan ketiga, pembelajaran membahas tentang manfaat gaya listrik dan listrik statis. Ketika proses pembelajaran, siswa mencari bahan-bahan di sekitarnya seperti daun, plastik, kertas, dan batu untuk melakukan percobaan listrik statis. Pertemuan terakhir membahas tentang alat elektronik sebagai pemanfaatan listrik dinamis. Siswa menemukan alat elektronik yang terdapat di sekolah seperti lampu, kipas angin, printer, dan lain lain.

Proses pembelajaran pada keempat pertemuan menerapkan tahapan-tahapan $C T L$ dengan indikator yang berbeda setiap pertemuannya. Tahapan-tahapan CTL menurut Lestari dan Yudhanegara (2017:39) yaitu grouping (pembentukan kelompok), modeling (permodelan), questioning (bertanya), learning community (masyarakat belajar), inquiry (penemuan), contructivism (konstruktivisme), authentic assesment (penilaian sebenarnya), serta reflection (refleksi). Setelah kegiatan awal pembelajaran, siswa dibentuk menjadi beberapa kelompok yang disusun dengan cara heterogen berdasarkan kemampuan yang dimiliki siswa. Hal tersebut dilakukan dengan tujuan siswa yang memiliki kemampuan lebih tinggi dapat berbaur dengan temannya yang memiliki kemampuan lebih rendah sehingga kegiatan diskusi dalam memecahkan masalah dapat terlaksana dengan optimal.

Selanjutnya siswa memperhatikan pemodelan yang dilakukan oleh guru maupun siswa dengan cara demonstrasi. Siswa diberikan kesempatan untuk bertanya apabila mengalami kesulitan. Kegiatan ini memiliki tujuan untuk mengetahui informasi lebih lanjut. Rasa sosial antar siswa juga ditingkatkan dalam pembelajaran. Siswa berdiskusi bersama teman kelompoknya untuk mendiskusikan permasalahan yang diberikan oleh guru maupun menyelesaikan soal yang tertera pada LKPD. Dalam tahap inkuiri, siswa diajak untuk keluar kelas dan memanfaatkan lingkungan sekolah. Suprijono (2012:86) mengemukakan bahwa inkuiri merupakan kata kunci dalam pembelajaran kontekstual. Siswa bukan hanya belajar memperoleh informasi baru, namun belajar memproses informasi. Siswa merekonstruksi pemahaman yang baru didapatkan dengan pemahaman yang telah lama dimilikinya. Dengan demikian, pengetahuan tersebut akan lebih lama bertahan dalam memori ingatan siswa, dibandingkan pengetahuan yang didapatkan dari hafalan semata.

Penilaian yang dilakukan oleh guru tidak berdasarkan nilai evaluasi saja melainkan dari proses pembelajaran yang dilakukan. Hal ini bertujuan apabila siswa mengalami kendala ketika proses pembelajaran, guru dapat segera mengatasinya (Trianto, 2013:118-119). Di akhir pembelajaran dilakukan kegiatan refleksi. Siswa diberikan kesempatan untuk menyebutkan kesan yang didapatkan selama mengikuti pembelajaran.

Berdasarkan uji hipotesis menggunakan independent samples t-test dan uji peningkatan rata-rata menggunakan $N$-Gain, dapat disimpulkan bahwa model $C T L$ berbasis lingkungan lebih efektif dibandingkan model $D I$ terhadap hasil belajar IPA.

Keefektifan model CTL berbasis lingkungan juga didukung dengan beberapa penelitian lain yaitu penelitian Desi Wulandari dan Nuning Setyowati (2017) berjudul Keefektifan Pendekatan CTL terhadap Hasil Belajar IPA Materi Sumber Daya Alam, dan penelitian yang dilakukan oleh Yayan Alpian, Aang Solahudin Anwar, dan Puspawati (2019) dengan judul Pengaruh Model Pembelajaran Contextual Teaching and Learning (CTL) terhadap Motivasi Belajar Siswa. Berdasarkan penelitian tersebut, pembelajaran dengan menerapkan model CTL lebih efektif apabila dibandingkan dengan model konvensional.

Penelitian yang dilakukan oleh Hasruddin (2015) berjudul Application of Contextual Learning to Improve Critical Thinking Ability of Students in Biology Teaching and Learning Strategies Class dan penelitian yang dilakukan oleh

Munir dan Riola Haya Nur (2017) berjudul The Development of English Learning Model Based on Contextual Teaching and Learning (CTL) for Junior High School Students in South Sulawesi juga menambahkan bahwa pembelajaran kontekstual dapat meningkatkan keterampilan berpikir kritis siswa.

Berdasarkan penjabaran hasil yang telah dianalisis dan kajian empiris yang relevan, penerapan model pembelajaran CTL berbasis lingkungan efektif dalam kegiatan pembelajaran IPA pada materi gaya, sehingga dapat dijadikan alternatif dalam pembelajaran IPA. 


\section{SIMPULAN}

Berdasarkan hasil analisis data tersebut menunjukkan bahwa $\mathrm{H}_{\mathrm{o}}$ ditolak dan $\mathrm{H}_{\mathrm{a}}$ diterima, artinya model pembelajaran $C T L$ berbasis lingkungan lebih efektif terhadap hasil belajar IPA siswa kelas IV SDN Gugus Jendral Sudirman Kecamatan Kayen Kabupaten Pati dibandingkan dengan model Direct Instruction (DI). Hal ini didukung dengan uji $N$-Gain yang menunjukkan peningkatan rata-rata hasil belajar kelas eksperimen lebih besar dari peningkatan rata-rata hasil belajar kelas kontrol.

\section{UCAPAN TERIMA KASIH}

Peneliti mengucapkan terima kasih kepada Ibu Desi Wulandari, S.Pd., M.Pd. selaku dosen pembimbing, Bapak Drs. A. Busyairi, M.Ag., dan Bapak Moh. Fathurrahman, S.Pd., M.Sn., sebagai mitra bestari serta Bapak Farid Ahmadi, S.Kom., M.Kom, Ph.D. selaku penyunting Bahasa Inggris yang telah berkenan membimbing artikel ini.

\section{DAFTAR PUSTAKA}

Alpian, Y., Anwar, A. S., \& Puspawati. 2019. Pengaruh Model Pembelajaran Contextual Teaching and Learning (CTL) terhadap Motivasi Belajar Siswa. Jurnal Basicedu. 3(3) : 894900.

Cholifah, N., Parmin, \& Dewi, N. R. 2016. Pengaruh Pendekatan Contextual Teaching and Learning (CTL) Berbasis Eksperimen terhadap Hasil Belajar Kognitif dan Sikap Ilmiah. Unnes Science Education Journal, 5(3) : 13431353.

Djamarah, Syaiful, B. \& Aswan, Z. 2010. Strategi Belajar Mengajar. Jakarta: Rineka Cipta.

Fausan, M. M. \& Pujiastuti, I. P. 2017. Pengaruh Pendekatan CTL Berbasis NHT terhadap Motivasi, Hasil Belajar IPA, dan Retensi Siswa. Jurnal Pendidikan Biologi Indonesia, 3(2) : 133140.

Hasruddin, Nasution M. Y., \& Rezeqi, S. 2015. Application of Contextual Learning to Improve Critical Thinking Ability of Students in Biology Teaching and Learning Strategies Class. International Journal of Learning, Teaching and Educational Research, 11(3) :109-116.
Lestari, K. E., Yudhanegara, \& Ridwan, M. 2017. Penelitian Pendidikan Matematika. Bandung: PT Refika Aditamak. International Journal of Science and Research (IJSR) : 2174-2179.

Munir, Nur, R.H. 2016. The Development of English Learning Model Based on Contextual Teaching and Learning (CTL) for Junior High School Students in South Sulawesi.

Nasir, C., Fata, I.A., Daud, B. \& Isniati, N. (2016). Figuring the Context of CTL Under 2013 Curiculum. A Journal of Culture, English Language, Teaching \& Literature .16(2) : 149-162.

Noor, F. M., \& Wilujeng, I. 2015. Pengembangan SSP Fisika Berbasis Pendekatan CTL untuk Meningkatkan Keterampilan Proses Sains dan Motivasi Belajar. Jurnal Inovasi Pendidikan IPA, 1(1): 73-85.

Peraturan Menteri Pendidikan dan Kebudayaan Nasional Republik Indonesia Nomor 21 tahun 2016 tentang Standar Isi Pendidikan Dasar dan Menengah.

Peraturan Menteri Pendidikan dan Kebudayaan Nasional Republik Indonesia Nomor 22 tahun 2016 tentang Standar Proses Pendidikan Dasar dan Menengah.

Peraturan Menteri Pendidikan dan Kebudayaan Nasional Republik Indonesia Nomor 37 tahun 2018 tentang Kompetensi Inti dan Kompetensi Dasar Kurikulum 2013 pada Pendidikan Dasar dan Menengah.

PISA 2018. Insights and Interpretations: OECD Better Policies for Better Lives.

Setiyoningsih, T. 2017. Pengelolaan Pembelajaran IPA Berbasis Lingkungan di SMPN 1 GabusGrobogan Jurnal Manajeman Pendidikan: 1-9.

Shoimin, Aris. 2014. 68 Model Pembelajaran Inovatif dalam Kurikulum 2013. Yogyakarta:Ar- Ruzz Media.

Slamet, A. 2017. Peningkatan Hasil Belajar Mahasiswa melalui Penerapan Pembelajaran Berbasis Lingkungan pada Materi Ekosistem. Jurnal Edukasi Cendekia, 1(1) : 40-48.

Suprijono, Agus. 2012. Cooperative Learning Teori \& Aplikasi Pakem. Yogyakarta: PUSTAKA PELAJAR. 
TIMSS. 2015. International Science Achievement. Boston: Boston Collage.

Trianto. 2011. Model-model Pembelajaran Inovatif Berorientasi Konstruktivistik. Jakarta: Pretasi Pustaka. 2013. Mendesain Model Pembelajaran Inovatif-Progresif. Jakarta: Prestasi Pustaka.

Wiyono, B. H. \& Budi, W. 2018. Pengaruh Metode Pembelajaran CTL terhadap
Hasil Belajar IPA Siswa Kelas VIII Ditinjau dari Kemampuan Berkomunikasi. Jurnal Ilmiah Pendidikan IPA, 5(1): 11-18.

Wulandari, D. \& Setyowati, N. 2017. Keefektifan Pendekatan CTL terhadap Hasil Belajar IPA Materi Sumber Daya Alam. Jurnal Pendidikan MIPA, 7(1): 50-57. 